\title{
PEMBIBITAN TANAMAN LADA PERDU SEBAGAI PENGGANTI LADA TANPA TIANG PANJAT DI DESA PULAU PANGGUNG KABUPATEN KAUR
}

\section{SEEDING OF SHRUB PEPPER PLANT AS A SUBSTITUTE PEPPER WITHOUT CLIMBING POLES FOR PULAU PANGGUNG VILLAGE, KAUR DISTRICT}

\author{
Oleh : \\ Helfi Eka Saputra ${ }^{1}$, Budi Harlianto ${ }^{2}$, Dwi Wahyuni Ganefianti ${ }^{l}$, Entang Inoriah ${ }^{l}$, Prasetyo ${ }^{1}$ \\ ${ }^{1}$ Program Studi Agroekoteknologi, Jurusan Budidaya Pertanian Fakultas Pertanian \\ Universitas Bengkulu \\ ${ }^{2}$ Jurusan Fisika Fakultas Matematika dan Ilmu Pengetahuan Alam Universitas Bengkulu \\ Email: hesaputra@unib.ac.id
}

\begin{abstract}
Pepper shrubs are a solution in pepper cultivation without climbing poles. The purpose of the service activity is to make the pepper seedling plants as a model for the community in Pulau Panggung Village, Kaur Regency, Bengkulu Province to overcome the obstacles on the climbing pole pepper plant. Community service activities are carried out by providing training in making shrub pepper seeds in Pulau Panggung Village, Kaur Regency. The results of the activity showed that the participants in making pepper seedlings had high enthusiasm. The success of this training activity was that participants could choose fruit branches as planting material for shrub pepper. The success of the fruit branches planted is marked by the presence of leaf buds that are formed. The conclusion of the service activity is that the making of shrub pepper seeds can be used as a new technique in pepper cultivation.
\end{abstract}

Keywords: cultivation,cuttings, fruit branch, seeding, shrub pepper

\section{PENDAHULUAN}

Tanaman lada merupakan salah satu jenis rempah yang memiliki permintaan besar dari dalam hingga luar negeri, hal ini dikarenakan lada kaya dengan minyak dan pati yang umumnya dimanfaatkan untuk berbagai keperluan. Di Indonesia, daerah-daerah penghasil lada adalah Bangka Belitung, Lampung, Kalimantan Timur, Sumatera Selatan dan Sulawesi Selatan (Yuhono, 2007; Kemala, 2015). Lada merupakan tanaman yang hanya tumbuh di daerah dengan ketinggian 300-1100 meter dari permukaan laut (dpl) dan memiliki curah hujan yang cukup tinggi. Lahan yang diperlukan juga mesti subur serta kaya dengan bahan organik. Salah satu daerah yang memenuhi kriteria tersebut adalah Kabupaten Kaur yang memiliki ketinggian 100-1000 meter dpl dan memiliki curah hujan yang tinggi mencapai $237,50 \mathrm{~mm}$, Rata-rata suhu udara mencapai $26,88^{\circ} \mathrm{C}$, dan 11 hari hujan per bulan. Lada bersifat sedikit pahit, pedas, hangat, dan antipiretik. Selain itu, lada mempunyai sebutan The King of Spice (Raja Rempah-Rempah) yang mana kebutuhan lada di dunia tahun 2000 mencapai 280.000 ton (Rukmana, 2003). Lada adalah salah satu tanaman yang berkembang biak dengan biji, namun banyak para petani lebih memilih melakukan penyetekkan untuk mengembangkannya. Batang tanaman lada tumbuh 
merambat pada suatu tiang, terkadang juga menjalar di permukaan tanah. Panjang batang bisa mencapai 15 meter, namun dalam budidaya tanaman lada, biasanya batang akan dipotong dan hanya disisakan sekitar 2,75-3 meter (Sarpian, 2003). Menurut Rostiana et al. (2017), produksi tanaman lada bisa mencapai 2,94 kg buah segar/ pohon.

Kabupaten Kaur pada tahun 2000 merupakan salah satu penghasil komoditas lada terbesar di Provinsi Bengkulu, jenis lada yang dikembangkan adalah lada panjat (pakai tiang tajar panjat). Namun mulai tahun 2006 sampai sekarang menurun drastis, hal ini dapat dilihat dari 13 jenis komoditi yang ditanam oleh masyarakat Kabupaten Kaur jenis tanaman Lada/Papper berada di urutan ke-7 dengan rincian keadaan tanaman : belum produktif $=201$ ha, produktif $=515$ ha, tidak produktif $=52$ ha dan hingga saat ini terus berkurang (Badan Pusat Statistik, 2016). Pengurangan tersebut disebabkan oleh banyaknya hama yang menyerang tiang panjat (tajar) yang merupakan komponen utama sebagai tempat menjalarnya tanaman lada. Tiang panjat yang terserang hama menyebabkan tanaman lada roboh dan akhirnya layu kemudian tanaman lada mati, sampai saat ini belum didapatkan jenis tanaman tiang panjat sebagai pengganti sehingga banyak petani yang mengganti jenis komoditi yang ditanam. Beberapa jenis tanaman tiang panjat yang digunakan oleh masyarakat di Kabupaten Kaur (Desa Pulau Panggung, Kecamatan Luas) yakni dedap biasa (memiliki duri) dan dedap minyak, seperti yang ditunjukkan pada Gambar 1 dan 2.
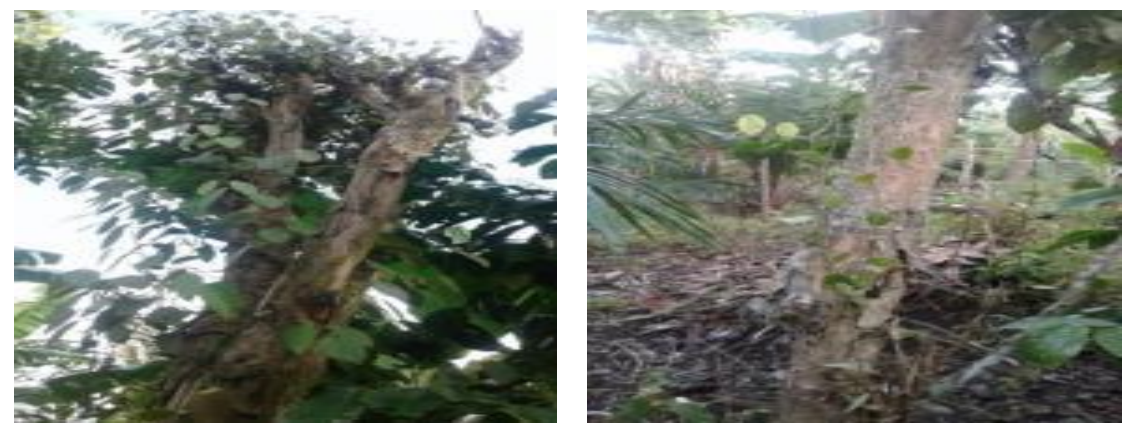

Gambar 1. Tanaman Lada Panjat di Desa Pulau Panggung (Ladanya masih produktif tapi tiang panjat sudah mati)
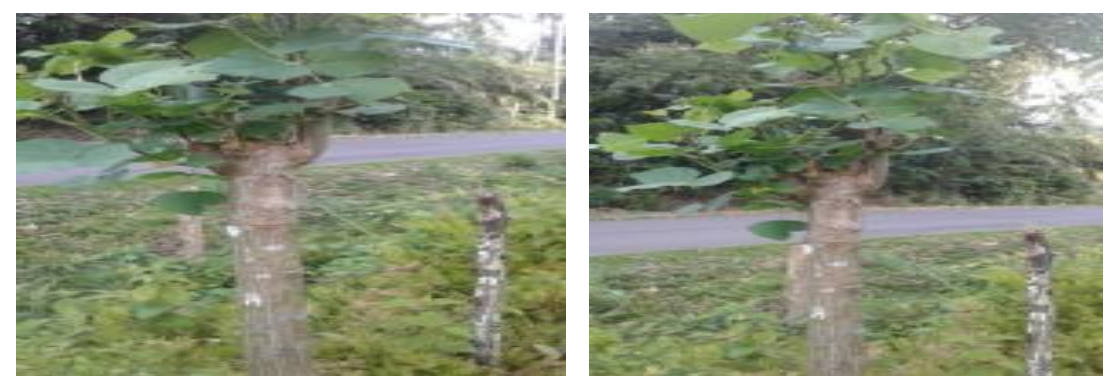

Gambar 2. Tanaman Lada Panjat di Desa Pulau Panggung (Tiang panjat masih hidup tapi mati ladanya tidak berkembang)

Hasil diskusi dengan beberapa masyarakat, bahwa banyak masyarakat yang tertarik untuk menanam lada jika ada jenis-jenis tiang panjat yang tahan hama atau jenis tanaman lada yang tanpa menggunakan tiang panjat seperti yang selama ini. Akhir-akhir ini sudah dikembangkan jenis tanaman lada yang lain yakni jenis lada perdu yang sampai saat ini 
belum banyak diketahui dan dikembangkan di Kabupaten Kaur termasuk Desa Pulau Panggung.

Hariyadi et al. (1996) melaporkan semua cabang lada baik cabang sekunder maupun tersier dapat digunakan sebagai bahan stek untuk membuat lada perdu. Sebagai salah upaya untuk mengatasi permasalahan pada tanaman lada panjat selama ini maka tim pengabdian dosen dari lembaga Penelitian dan Pengabdian Kepada Masyarakat Universitas Bengkulu melakukan pengabdian pembinaan pembuatan bibit tanaman lada perdu untuk mengatasi kendala-kendala yang muncul pada tanaman lada panjat di Desa Pulau Panggung. Tujuan pengabdian kepada masyarakat ini adalah untuk membuat bibit tanaman lada perdu sebagai percontohan bagi masyarakat di Desa Pulau Panggung Kabupaten Kaur Provinsi Bengkulu untuk mengatasi kendala pada tanaman lada tiang panjat.

\section{METODE PENGABDIAN}

Kegiatan Pengabdian dilakukan kepada Kelompok Tani Gelanggang Sakti, Desa Pulau Panggung, Kabupaten Kaur. Pengabdian diawali dengan adanya surat permintaan dari Kelompok Tani pada tanggal 9 Maret 2018. Kegiatan pengabdian dilakukan hingga 14-15 Juli 2018. Kegiatan Pengabdian dilakukan dengan dua tahapan yaitu tahapan satu adalah penyampaian informasi, diskusi dan tanya jawab dengan tujuan meningkatkan pemahaman masyarakat terutama kelompok tani tentang pembuatan bibit lada perdu. Kegiatan ini dimulai dengan pemaparan dan penyampaian informasi tentang pembuatan bibit lada perdu, pemilihan stek cabang buah sebagai bahan tanam dan budidaya lada perdu dengan diskusi yang melibatkan pemahaman peserta. Setelah peserta mamahami teori pemilihan cabang buah sebagai bahan tanam dan pembuatan bibit lada perdu, dilanjutkan pelatihan pembuatan bibit lada perdu. Tahapan kedua adalah pelatihan pembuatan bibit lada perdu. Langkah-langkah yang dilakukan untuk pembuatan media pembibitan lada perdu seseuai dengan metode yang dikembangkan oleh Zaubin et al.(1992), Zaubin et al. (1994) dan Utoyo et al. (2018) adalah sebagai berikut :

1. Persiapan sungkup dan media semai

2. Persiapan bahan tanam

3. Penyemaian dan pemeliharaan

\section{HASIL DAN PEMBAHASAN}

Pelaksanaan program pengabdian di Kelompok Tani Gelanggang Sakti, Desa Pulau Panggung, Kecamatan Luas, Kabupaten Kaur berjalan dengan baik. Program pengabdian diawali dengan pemberian materi atau pengenalan budidaya lada perdu ke anggota kelompok tani. Lada perdu merupakan tanaman lada yang memiliki keragaan secara perdu sehingga tidak perlu adanya lanjaran. Tidak adanya lanjaran ini yang menjadi prinsip penamaan lada menjadi lada perdu. Tanaman lada memiliki dua jenis cabang, yaitu (1) cabang yang tumbuh lurus ke atas atau sulur panjat dan (2) cabang yang menghasilkan buah/biji lada atau sulur buah. Beberapa cabang yang diperoleh dari tunas tambahan (sulur cacing) atau tunas gantung tidak dapat menghasilkan akar yang kuat menempel pada mata tunas dan tidak cocok sebagai bibit tanaman. Cabang pohon yang tumbuh dari bawah yang memiliki akar yang tunggang yang tumbuh pada musim penghujan adalah bibit yang biasanya dipilih untuk perkebunan komersial. Sulur buah biasanya dijadikan bibit untuk lada perdu. Pada tahap awal program pengabdian, peserta pelatihan diberikan pengetahuan tentang cara memilih cabang (bahan tanam), cara menyiapkan media tanam, cara menyiapkan sungkup, cara membuat stek bibit 
lada perdu dan pemeliharaan lada yang sudah di stek. Pemberian materi tentang pembuatan bibit lada juga ditekankan dengan slogan "mudahnya panen lada tanpa panjat". Slogan yang dibuat membuat peserta PPM menjadi lebih tertarik dan berkeinginan kuat untuk menanam lada perdu. Antusiasme peserta PPM terlihat dari adanya beberapa anggota yang ingin langsung ke lapangan untuk mengetahui dan memilih cabang buah secara benar (Gambar 3).
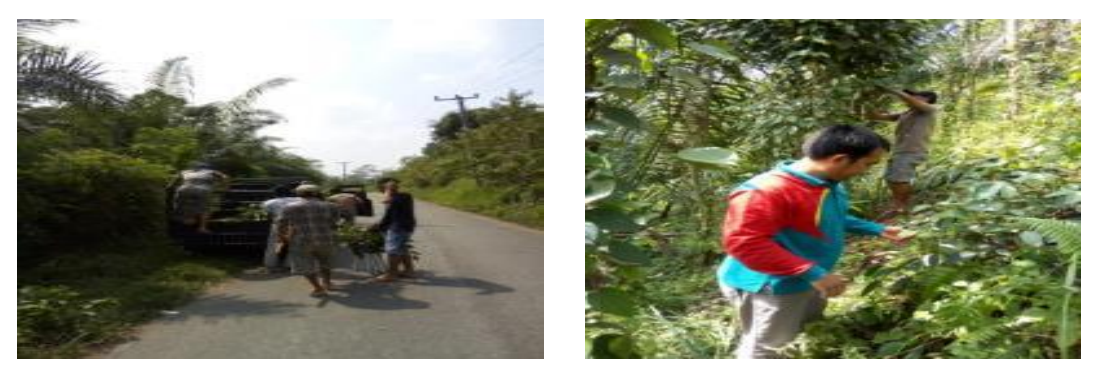

Gambar 3. Peserta PPM sedang mengambil sulur buah (bahan tanam).

\section{Teknik Pembuatan Media Pembibitan}

Kegiatan penyampaian materi dan diskusi tentang pembuatan bibit lada perdu dilakukan di salah satu rumah anggota kelompok tani. Penyampaian materi dilakukan dengan pemaparan kelebihan dan budidaya lada perdu secara ringkas. Metode penyampaian materi dilakukan dengan menyebarkan selebaran dalam bentuk power point tentang pembuatan bibit lada perdu. Selebaran power point yang dibagikan kepada sasaran PPM. Kegiatan pemaparan dan diskusi dengan peserta PPM disajikan pada Gambar 4.

Hal pokok dalam pembuatan bibit lada perdu adalah pemilihan cabang buah. Kegiatan awal yang dilakukan dalam pembuatan bibit lada perdu adalah pembuatan sungkup. Sungkup yang dibuat merupakan sungkup yang bahannya banyak tersedia di sekitar desa. Pemilihan bahan yang banyak tersedia di sekitar desa adalah bambu. Kerangka sungkup dari bambu dibuat seperti Gambar 5.

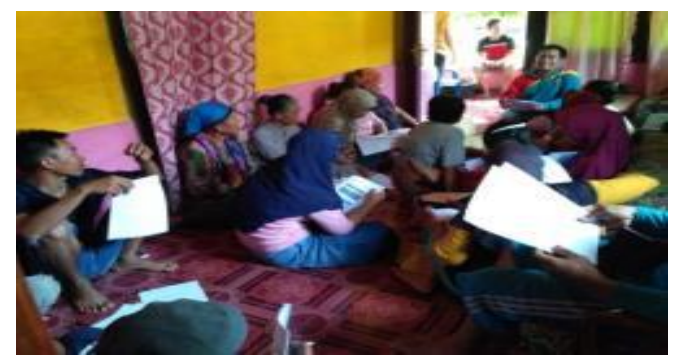

Gambar 4. Penyampaian materi dan diskusi tentang pembibitan lada perdu

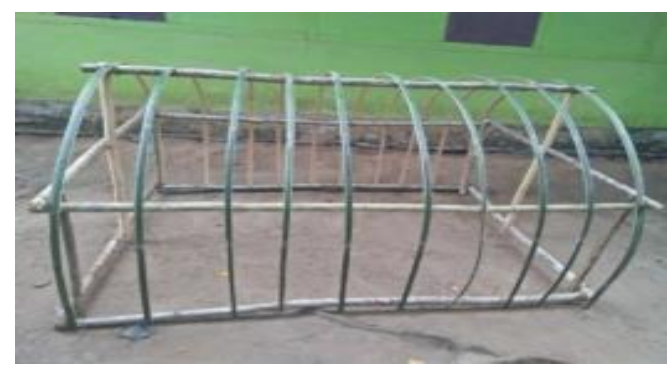

Gambar 5. Kerangka sungkup 
Setelah kerangka sungkup dibuat, langkah selanjutnya adalah pengisian polibag, diikuti dengan pembuatan cabang buah sebagai bahan tanam, penanaman cabang buah di dalam polibag. Media tanam yang digunakan adalah campuran tanah dengan pupuk kandang sapi. Perbandingan tanah dengan pupuk kandang sapi adalah 2:1 (v/v). Setelah diperoleh media tanam yang sesuai dikehendaki, selanjutnya adalah memasukkan media tanam ke dalam polibag. Kegiatan pengisian polibag dilakukan bersama-sama sesama peserta PPM (Gambar 6).

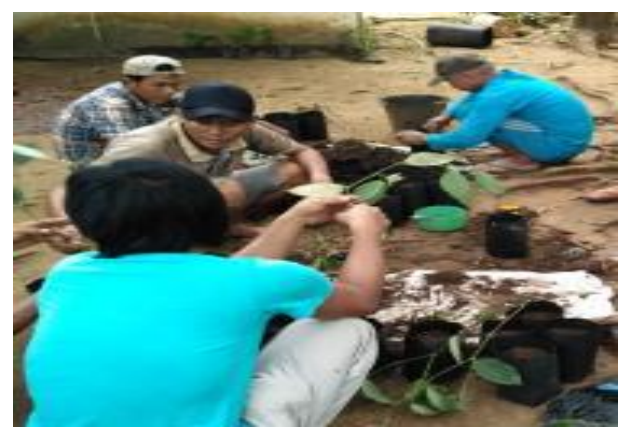

Gambar 6. Pengisian polibag dengan media tanam

Setelah pembuatan sungkup dan pengisia polibag selesai, selanjutnya disiapkan stek cabang buah. Ukuran stek cabang buah yang disiapkan adalah $15-30 \mathrm{~cm}$. Stek cabang yang dipilih hendaknya memiliki keragaan tanaman yang baik. Kriteri stek cabang buah yang dipilih juga memiliki kriteria ada cabang dua dan memiliki satu buku untuk dimasukkan di bawah tanah. Setelah stek cabang buah dipilih seseuai kriteria, langkah selanjutnya adalah melakukan keratin di bagian bawah stek. Luka yang terbentuk dari keratin selanjutnya diberi pasta zat pengatur tumbuh (Gambar 7).

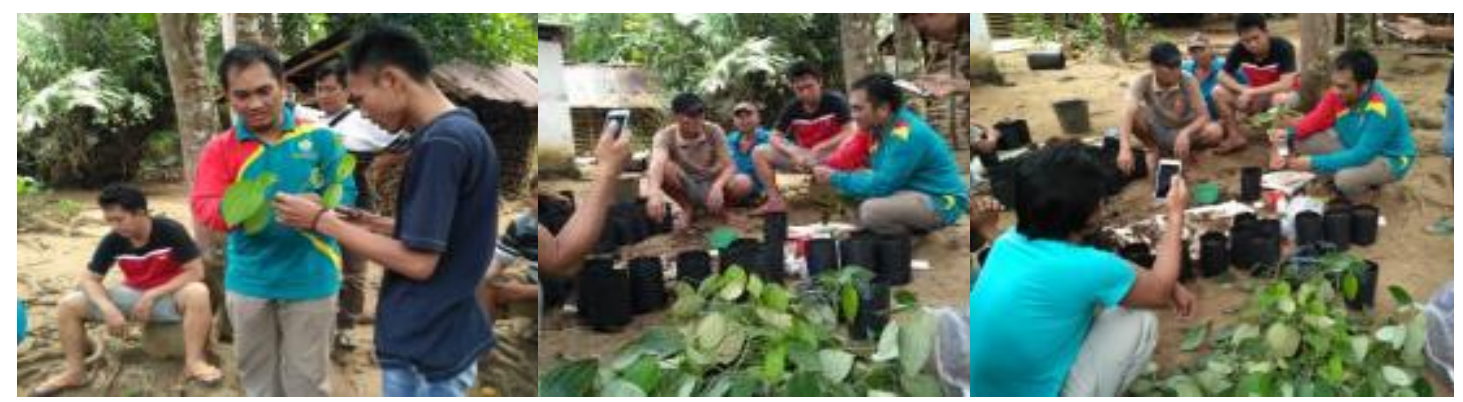

Gambar 7. Pemilihan stek cabang buah, pengeratan ujung stek dan pemberian pasta zpt di bagian stek yang dilukai.

Langkah terakhir yang dilakukan setelah pemberian pasta zpt di bagian stek yang luka maka langkah selanjutnya ada menanam stek cabang buah ke dalam polibag. Selanjutnya polibag yang sudah ditanam stek cabang buah disusun rapi di dalam kerangka sungkup. Setelah semua polibag tersusun di dalam sungkup maka kemudian kerangka sungkup dilapisi plastik bening tanpa ada celah. Alternatif lain yang bisa dilakukan adalah dengan melapisi kerangka sungkup terlebih dahulu dengan plastik (Gambar 8). 

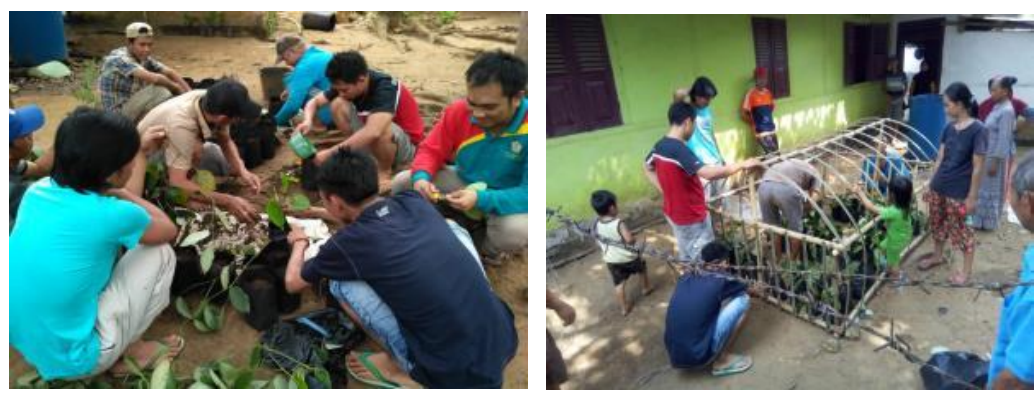

Gambar 8. Penyusunan polibag di dalam sungkup.

Setelah semua polibag selesai disusun, langkah selanjutnya adalah melapiskan dengan plastik bening. Pelapisan kerangka sungkup dengan plastik ditujukan agar kelembaban di dalam sungkup tetap terjaga sehingga stek cabang dapat segera berakar dan bertunas. Selanjutnya setelah kerangka sungkup dilapisi plastik bening maka kegiatan selanjutnya adalah pemeliharan stek hingga berakar dan bertunas (Gambar 9). Mansur dan Sarwanda (2008) melaporkan bahwa waktu terbaik stek di dalam sungkup adalah 7 minggu sehingga pada pengabdian ini lama stek di dalam sungkup adalah 7 minggu.
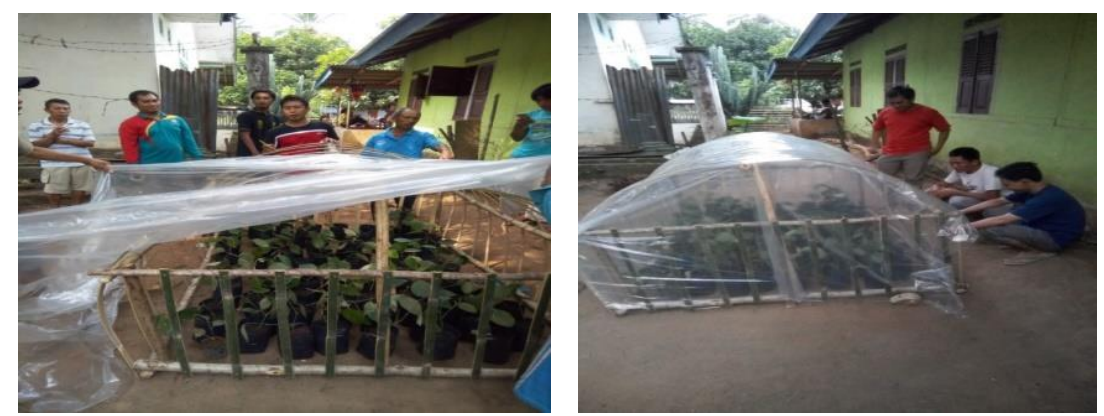

Gambar 9. Pemasangan plastik sungkup dan pemeliharaan stek.

\section{KESIMPULAN DAN SARAN}

\section{Kesimpulan}

Berdasarkan uraian yang telah disampaikan dalam pembahasan, dapat disimpulkan sebagai berikut :

a. Pengabdian pembuatan bibit lada perdu dapat dijadikan sebagai teknik baru dalam budidaya lada bagi kelompok tani Gelanggang Sakti.

b. Metode ceramah dan demonstrasi/peragaan dalam pengabdian pembuatan bibit lada perdu dinilai cukup efektif untuk menyampaikan tujuan pengabdian.

\section{Saran}

a. Kegiatan pengabdian ini diharapkan ke depan dapat sampai membuka lahan baru lada perdu bagi peserta PPM (kelompok tani Gelanggang Sakti).

b. Program pengabdian ini diharapkan dapat dilanjutkan pada tahun-tahun berikutnya di lokasi lain sebagai alternatif baru dalam budidaya lada. 


\section{DAFTAR PUSTAKA}

Badan Pusat Statistik, 2016, Kecamatan Luas Dalam Angka tahun 2016, BPS Kab. Kaur, Kaur.

Hariyadi, I., Darmawan., R, Zaubin, 1996, Pengaruh jenis setek dan media pembibitan terhadap pertumbuhan bibit tanaman lada (Piper nigrum L.), Bul. Agron, 24 (1) : 6-9.

Kemala, S., 2015, Strategi pengembangan sistem agribisnis lada untuk meningkatkan pendapatan petani, Perspektif 6 (1) : 47-54.

Mansur, U., Sarwanda, 2008, Teknik penyungkupan setek lada perdu bertapak di persemaian untuk menghasilkan benih yang optimal, Buletin Teknik Pertanian 13 (1) : 30-32.

Rostiana, O., D, Manohara., A, Ruhnayat., Wiratno, 2017, Karakteristik produksi dan mutu lada lokal Kalimantan Timur, Buletin Penelitian Tanaman Rempah dan Obat 28 (2) : 113-126.

Rukmana, R., 2003, Tanaman Perkebunan: Usaha Tani Lada Perdu, Yogyakarta : Penerbit Kanisius, Hal 7.

Sarpian, T., 2003, Pedoman Berkebun Lada dan Analisis Usaha Tani, Yogyakarta : Penerbit Kanisius, Hal 22-27.

Utoyo, B., A, R, Gusta., Y, Sukmawan., S, Made, 2018, Pengembangan unit penangkar bibit lada berkualitas di politeknik negeri Lampung, J-DINAMIKA 3 (2) : 96-100.

Yuhono, J,T., 2007, Sistem agribisnis lada dan strategi pengembangannya, Jurnal Litbang Pertanian 26 (2) : 76-81.

Zaubin, R., N, Indrati., D, Elphywika, 1994, Pengaruh Jumlah Daun tempat Pemotongan Setek Terhadap Pertumbuhan Akar Setek Cabang Buah Lada, Pemberitaan Penel, Tan, Industri, XIX (3-4) : 66-70.

Zaubin, R., T, Sunarti., A,M, Murni., 1992, Rooting of Black Pepper Plagiotropic Cuttings After Treated with Sucrose and IBA (Indole Butyric Acid), J. Spice and Medicinal Crops 1 (1): 1-4. 